\title{
Oxidative Stress Markers in Young Patients with Acute Myocardial Infarction and Their Correlation with Cardiac Enzymes
}

\author{
Akut Miyokard Enfarktüsü Geçiren Genç Hastalarda Oksidatif Stres Belirteçleri \\ ve Kardiyak Enzimlerle İlişkisi
}

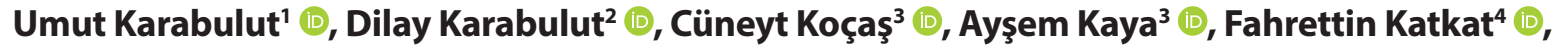 \\ Zerrin Yiğit ${ }^{3}$ (1)
}

'Department of Cardiology, Acıbadem International Hospital, İstanbul, Turkey

2Department of Cardiology, Istanbul Bakırköy Sadi Konuk Education and Research Hospital, İstanbul, Turkey

${ }^{3}$ Department of Cardiology, Institute of Cardiology, Istanbul University-Cerrahpasa, İstanbul, Turkey

${ }^{4}$ Department of Cardiology, İstanbul Bağcılar Education and Research Hospital, İstanbul, Turkey

ORCID ID: U.K. 0000-0002-3947-9173; D.K. 0000-0003-1896-0096; C.K. 0000-0002-3927-2703; A.K. 0000-0003-3137-821X; F.K. 0000-0002-3917-3449;
Z.Y. 0000-0002-8368-7906

Cite this article as: Karabulut U, Karabulut D, Kocas C, Kaya A, Katkat F, Yigit Z. Oxidative stress markers in young patients with acute myocardial infarction and their correlation with cardiac enzymes. Experimed 2021; 11(2): 73-80.

\section{ABSTRACT}

Objective: The relationship between oxidative stress and acute myocardial infarction has been shown in studies. Total antioxidant status (TAS), total oxidant status (TOS), and oxidative stress index (OSI) reflect the oxidative balance. The risk factors, clinical features, and prognosis of acute myocardial infarction (AMI) in young patients differ from older counterparts. This study aims to determine the oxidative stress in the young acute AMI patients and its' correlation with cardiac markers within 48 hours by the quantitative measurement of TAS, TOS, and OSI.

Material and Method: In this prospective, controlled study, we included 50 patients who were 45 years old or younger and diagnosed with AMI, as well as 20 healthy individuals as the control group. TOS and TAS were measured from venous blood samples via the spectrophotometric method. The oxidative stress index was obtained from these parameters.

Results: Forty-five of totally 50 patients were male, and the mean age was (36 \pm 6.8$)$. TOS and OSI values were found significantly higher than in the control group ( $p=0.002, p=0.005$, respectively). TAS values were found not to be different from the control group $(p=0.46)$. A significant correlation was found between $\mathrm{CK} 0$. hour (h.), and TOS 0. h., CK-MB 0. h., and TOS 0. h., CK 48. h. and OSI 48. h., CK-MB 48. h. and OSI 48. $h$., respectively $(r=0.36, p=0.008),(r=0.46, p=0.001)$, $(r=0.32, p=0.03),(r=0.36, p<0.01)$.

Conclusion: Oxidative stress increases in the early hours of AMI. The TOS and OSI values are correlated with cardiac markers at only some time points, and their prognostic values are limited in young AMI patients. TAS is not correlated with cardiac markers.

Keywords: Total antioxidant status, total oxidant status, oxidative stress index, myocardial infarction

\section{ÖZ}

Amaç: Oksidatif stres ile akut miyokard infarktüsü (AMi) arasındaki ilişki pek çok çalışma ile gösterilmiştir. Total antioksidan seviyesi (TAS), total oksidan seviyesi (TOS) ve oksidatif stres indeksi (OSI) oksidatif dengeyi yansıtır. Genç hastalarda AMi'nin risk faktörleri, klinik özellikleri ve prognozu, yaşlı gruptan farklıdır. Bu çalışma TAS, TOS ve OSI'nin kantitatif ölçümü ile genç AMi hastalarında 48 saat içerisindeki seyrini ve kardiyak belirteçlerle ilişkisini belirlemeyi amaçlamaktadır.

Gereç ve Yöntem: Bu prospektif, kontrollü çalışmaya 45 yaş ve altında AMI tanısı almış 50 hasta ve kontrol grubu olarak 20 sağlıklı birey dahil edilmiştir. TOS ve TAS, venöz kan örneklerinden spektrofotometrik yöntemle ölçülmüştür. Oksidatif stres indeksi bu parametreler üzerinden elde edilmiştir.

Bulgular: Toplam 50 hastanın kırkbeşi erkek ve ortalama yaş $(36 \pm 6,8)$ idi. TOS ve OSI değerleri kontrol grubuna göre anlamlı olarak yüksek bulundu $(p=0,002 ; p=0,005)$. TAS değerleri kontrol grubundan farklı bulunmadı $(p=0,46)$. Sırasıyla CK 0 . saat (s) ve TOS 0. s., CK-MB 0. s. ve TOS 0. s., CK 48. s. ve OSI 48. s., CK-MB 48. s. ve OSI 48. s. arasında anlamlı bir korelasyon olduğu bulundu $(r=0,36$, $p=0,008 ; r=0,46, p=0,001 ; r=0,32, p=0,03 ; r=0,36, p<0,01$ ).

Sonuç: Oksidatif stres AMI'nin erken saatlerinde artmaktadır. TOS ve OSI değerleri, yalnızca belirli zaman dilimlerinde kardiyak belirteçlerle ilişkilendirebilmekte ve genç AMi hastalarında prognostik değerleri sınırlı olmaktadır. TAS, kardiyak belirteçlerle ilişkili bulunmamıştır.

Anahtar Kelimeler: Total antioksidan seviyesi, total oksidan seviyesi, oksidatif stres indeksi, miyokard infarktüsü 


\section{INTRODUCTION}

Oxidative stress plays a critical role in the pathophysiology of many important diseases. It is defined as the disturbance of the balance between the oxidative processes and the body's antioxidant defense mechanisms. As a result, various damages occur in DNA, protein, and lipid structures via reactive oxygen species (ROS) $(1,2)$. Oxidant stress promotes atherosclerosis through several mechanisms, such as endothelial dysfunction, inflammation, immune response, and thrombus formation. Oxidized lipids initiate a cascade of vascular events, resulting in atherosclerotic plaques (3).

The effect of oxidative stress on acute coronary syndrome's pathogenesis is lipid peroxidation caused by ROS reacting with unsaturated fatty acids (4-6). The physiological or pathological roles of ROS depend on their concentration. ROS involves physiological processes; high level of ROS can modify the molecular structure and function of intracellular molecules. Also, peroxide $\left(\mathrm{O}_{2}^{-}\right)$may react with nitric oxide (NO), leading to the inactivation and loss of the process of $\mathrm{NO}$, resulting in the generation of peroxynitrite $\left(\mathrm{ONOO}^{-}\right)$species and endothelial dysfunction. These deleterious events may trigger cardiomyocyte dysfunction in the heart, resulting in contractile dysfunction, impaired cardiac remodeling, fibrosis, and heart failure (7). Antioxidants inhibit or delay oxidative damage. There are several biological antioxidants such as superoxide dismutase (SOD), glutathione peroxidase (GPD), and catalases that collectively reduce superoxide/hydrogen peroxide (or lipid hydroperoxides) to water (or lipid hydroxides). Antioxidants reduce myocardial damage by reducing lipid peroxidation, reperfusion damage, and thrombosis in acute myocardial infarction (AMI) (3).

The measurement of oxidants and antioxidants separately is neither practical nor cost-effective. Total antioxidant status (TAS), total oxidative stress (TOS), and oxidative stress index (OSI) reflect the oxidative balance (8). TOS and TAS can be easily measured from venous blood samples using the spectrophotometric method. The oxidative stress index (OSI), used as the oxidative stress marker, can be calculated using these two parameters.

The relationship between oxidative stress and acute coronary syndrome, ischemic heart failure, and ischemia-reperfusion damage after myocardial infarction (MI) has been demonstrated by several studies $(9,10)$. The risk factors, clinical features, and prognosis of AMI in young adults differ from those of older patients. While the incidence of AMI in young patients varies between $2-10 \%$, it is increasing. Younger patients with ST-elevation myocardial infarction (STEMI) were more likely to be male, obese, smokers with hypertriglyceridemia and low high density lipoprotein (HDL) levels, and less likely to have other comorbid conditions than older patients. Younger patients had a better outcome than older patients without an apparent difference in repeated percutaneous coronary intervention (PCl) frequency or reinfarction (11). The frequency of coronary artery disease increases, with the age of onset shifting towards a younger generation. Several studies have reported coronary artery disease in young adult patients $(5,12,13,14,15)$. However, studies examining oxidative stress in young patients with AMI are limited.

This study aimed to determine the oxidative stress in young acute AMI patients and its correlation with cardiac markers within 48 hours via the quantitative measurement of TAS and TOS and the calculated OSI. The relationship between oxidative stress and the infarct type and the number of stenotic vessels was also examined. We aimed to demonstrate the characteristics and prognostic value of oxidative stress markers in the early phases of AMI in young patients.

\section{MATERIAL AND METHOD}

In this prospective, controlled study, we included 50 patients who were 45 years old or younger and diagnosed with AMI and 20 healthy individuals as a control group. Ethical approval was obtained from the Regional Ethics Committee (No:2020-39), and written consent was obtained from all patients. Patients with stable and unstable angina, malignant hypertension, cardiogenic shock, chronic kidney failure, chronic obstructive pulmonary disease, and sleep apnea were excluded from the study.

The demographic data, medical history, laboratory findings, and 48 hours of follow-up measurements of troponin-l, creatine kinase (CK), and CK-MB were recorded. Venous blood samples were obtained at admission (0. hour ( $h$.) of diagnosis) and 6., 12., 24. and 48. h. after diagnosis. Samples were collected in 8-10 $\mathrm{ml}$ dry blood tubes, centrifuged, separated into godets, and stored at $-80^{\circ} \mathrm{C}$. The total TOS and TAS were measured via the spectrophotometric method in an Opera-Technician autoanalyzer (Bayer). CK, creatine kinase muscle-brain (CK-MB), and troponin-I values were measured at the exact times.

Erel's method was used to measure TOS (16). Briefly, the oxidants in the sample oxidize the ferrous ion-o-dianicidine complex to ferric ions. Ferric ions form a colored complex with xylenol orange in an acidic environment. The intensity of the color is related to the amount of oxidants in the sample and is measured spectrophotometrically (16). The results were reported as $\mathrm{mmol} / \mathrm{L}$.

Erel's method was also used to measure TAS (16). Briefly, an $\mathrm{Fe}^{+2}$-o-dianicidine complex forms a Fenton reaction with hydrogen peroxide and generates $\mathrm{OH}^{*}$ (hydroxyl) radicals. This potent reactive oxygen-type reducer reacts with the colorless o-dianicidine molecule at a low pH to form the yellow-brown dianisdyl radical. Dianisdyl radicals cause advanced oxidation reactions and increase color formation. However, antioxidants in the samples suppress these oxidation reactions and stop color formation. Similar to the measurement of TOS, this reaction is measured via a spectrophotometer (16). The results were reported as $\mathrm{mmol} / \mathrm{L}$.

OSI is calculated using the following equation: TOS/TAS $\times 100$. 


\section{Statistical analysis}

Quantitative variables were presented as (mean \pm standard deviation). Categorical variables were shown as $\mathrm{n}(\%)$. The Kolmogorov-Smirnov test was used to determine the distribution of continuous data. Normally distributed continuous data were compared via a Student's t-test, and multiple data were compared with ANOVA tests. Non-normally distributed continuous data were compared with Mann-Whitney-U and Kruskal-Wallis tests. Categorical data were compared using the chi-square test. Pearson's test was used to examine the correlations of variables. All statistical analyses were conducted using SPSS software version 22 (IBM Corp., Armonk, NY). Variables were discussed at a $95 \%$ confidence interval, and $p<$ 0.05 was considered significant.

\section{RESULTS}

A total of 50 patients and 20 healthy individuals were included in this study. Forty-five patients (90\%) were male, and the mean age was (36 \pm 6.8 ) years. Smoking ( $82 \%$ ) and hypertension (78\%) were the most common traditional risk factors in young adult MI patients. Demographic data, cardiac risk factors, infarct type and localization, culprit vessel, number of stenotic vessels, and treatment strategies in STEMI patients are shown in Table 1.

The most frequent localizations in STEMI patients were anterior $(38 \%)$ and interior (28\%). The most common culprit lesion was the left anterior descending (LAD) artery (66\%). Primary PCI $(52 \%)$ was the most common reperfusion strategy in patients with STEMI.

The mean TOS values at admission and 6., 12., 24. and 48. $\mathrm{h}$. after diagnosis were $15.6 \pm 10.7,16.1 \pm 9,14.7 \pm 7.2,17 \pm 11.1$, and $13.4 \pm 7.0 \mathrm{mmol} / \mathrm{L}$, respectively.

The mean TAS values at admission and 6., 12., 24. and 48. $\mathrm{h}$. diagnosis were $0.79 \pm 0.21,0.84 \pm 0.26,0.83 \pm 0.28,0.80 \pm 0.24$, and $0.81 \pm 0.24 \mathrm{mmol} / \mathrm{L}$, respectively.

The mean OSI at admission and 6., 12., 24. and 48. h. after diagnosis were $1854 \pm 898.6,1968 \pm 1235,1902 \pm 878,2328 \pm 1673$, and $1789 \pm 854$, respectively.

The TOS $(p=0.002)$ and OSI $(p=0.005)$ values of young AMI patients at admission were significantly higher than those of the control group. The TAS values of young AMI patients at admission were not different from those of the control group $(p=0.46)$ (Table 2).

The TOS value was increased in 6. h. after diagnosis, followed by a partial decrease until 12. $\mathrm{h}$ after diagnosis. Then, the TOS value increased again, reaching a peak level 24. h. after diagnosis, before decreasing until 48. h. after diagnosis (Figure 1). The TAS value increased until 6 . h. after diagnosis before plateauing for the study period's remainder (Figure 2). Like the TOS value, the OSI value increased until 6 . $\mathrm{h}$. after diagnosis, followed by a partial decrease until 12. h. after diagnosis, then peaked at 24. h. after diagnosis before decreasing until $48 \mathrm{~h}$. after diagnosis (Figure 3 ).
Table 1. Baseline characteristics and initial oxidative stress markers of patients.

\begin{tabular}{|c|c|}
\hline Age & $36 \pm 6.8$ \\
\hline Male & $45(90 \%)$ \\
\hline Hypertension & $39(78 \%)$ \\
\hline Hyperlipidemia & $34(68 \%)$ \\
\hline Smoking & $41(82 \%)$ \\
\hline Family history & $31(62 \%)$ \\
\hline Diabetes mellitus & $11(22 \%)$ \\
\hline ST-elevation miyocardial infarction & $36(72 \%)$ \\
\hline Non-ST elevation myocardial infarction & $14(28 \%)$ \\
\hline Anterior myocardial infarction & $19(38 \%)$ \\
\hline Inferior myocardial infarction & $14(28 \%)$ \\
\hline Anteroseptal myocardial infarction & $2(4 \%)$ \\
\hline Lateral myocardial infarction & $1(2 \%)$ \\
\hline Left anterior descending & $33(66 \%)$ \\
\hline Circumflex & $13(26 \%)$ \\
\hline Right coronary artery & $22(44 \%)$ \\
\hline Left main coronary artery & $1(2 \%)$ \\
\hline Primary percutaneous coronary intervention & $26(52 \%)$ \\
\hline Tissue plasminogen activator & $7(14 \%)$ \\
\hline Streptokinase & $2(4 \%)$ \\
\hline Rescue percutaneous coronary intervention & $2(4 \%)$ \\
\hline Single-vessel & $33(66 \%)$ \\
\hline Two-vessel & $11(22 \%)$ \\
\hline Three-vessel & $4(\% 8)$ \\
\hline BUN mg/dl & $14.1 \pm 4.3$ \\
\hline Creatinine $\mathrm{mg} / \mathrm{dl}$ & $0.9 \pm 0.2$ \\
\hline Glucose $\mathrm{mg} / \mathrm{dl}$ & $129 \pm 63$ \\
\hline $\mathrm{HbA1c}$ & $8.3 \pm 2$ \\
\hline Hemoglobin mg/dl & $14.4 \pm 1.77$ \\
\hline WBC $m g / d l$ & $14600 \pm 1100$ \\
\hline Uric acid $m g / d l$ & $5.2 \pm 1.1$ \\
\hline Total cholesterol $\mathrm{mg} / \mathrm{dl}$ & $201 \pm 44$ \\
\hline Low density lipoprotein $\mathrm{mg} / \mathrm{dl}$ & $130.2 \pm 33.2$ \\
\hline High density lipoprotein mg/dl & $36 \pm 6,6$ \\
\hline Triglyceride $\mathrm{mg} / \mathrm{dl}$ & $197 \pm 133$ \\
\hline Troponin-I (0. hour) mg/dl & $0.09 \pm 0.22$ \\
\hline Creatine kinase ( 0 . hour) $\mathrm{mg} / \mathrm{dl}$ & $229.4 \pm 124.8$ \\
\hline Creatine kinase muscle-brain ( 0 . hour) $\mathrm{mg} / \mathrm{dl}$ & $25 \pm 15.7$ \\
\hline Total oxidant status (0. hour) $\mathrm{mmol} / \mathrm{L}$ & $0.79 \pm 0.21$ \\
\hline Total antioxidant status ( 0 . hour) $\mathrm{mmo} / \mathrm{L}$ & $0.79 \pm 0.21$ \\
\hline Oxidative stress index (0. hour) & $1854 \pm 898$ \\
\hline
\end{tabular}


Table 2: Comparison of oxidative stress parameters between patients and the control group.

\begin{tabular}{lccc}
\hline & Myocardial infarction $(\mathbf{n}=\mathbf{5 0})$ & Control group $(\mathbf{n = 2 0 )}$ & p value \\
\hline Total oxidant status (0. hour) & $17.33 \pm 12.19$ & $11.31 \pm 2.85$ & $\mathbf{0 . 0 0 2}$ \\
\hline Total antioxidant status (0. hour) & $0.80 \pm 0.25$ & $0.77 \pm 0.56$ & 0.46 \\
\hline Oxidative stress index (0. hour) & $2019.7 \pm 1011.3$ & $1487.9 \pm 434.24$ & $\mathbf{0 . 0 0 5}$ \\
\hline
\end{tabular}

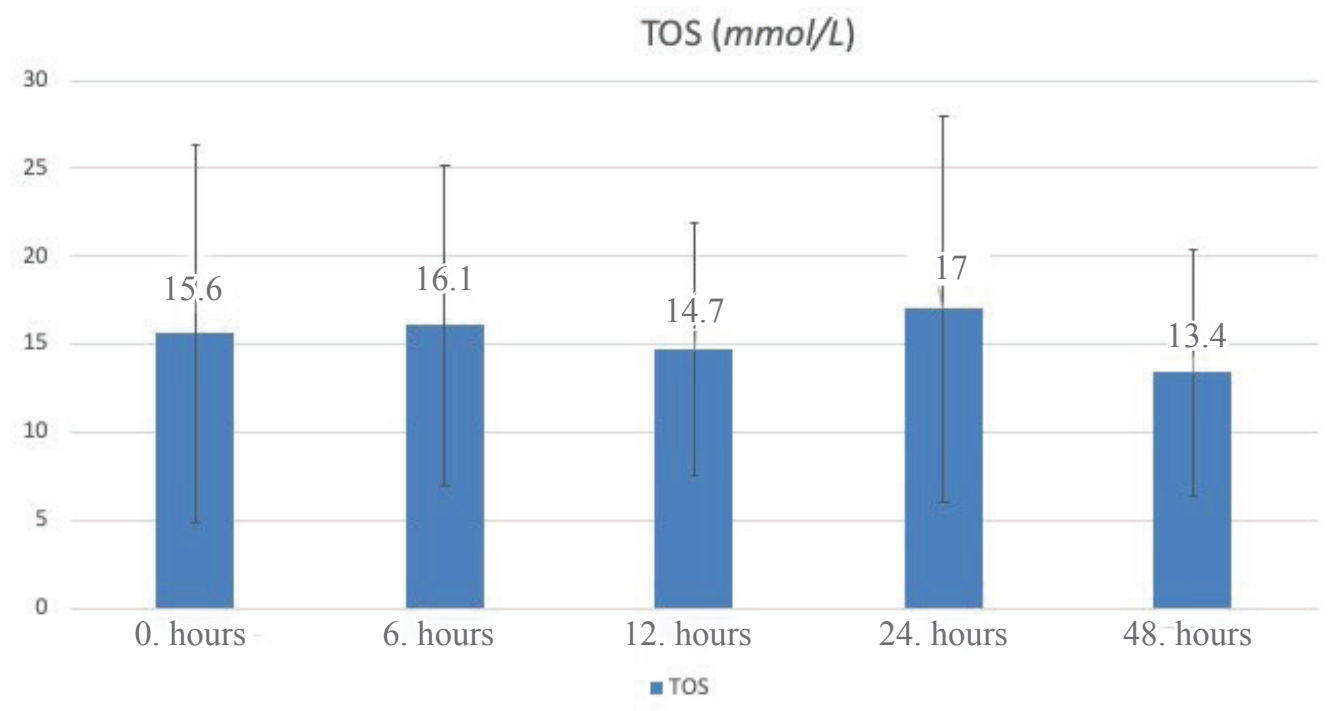

Figure 1. Course of TOS within 48 hours: TOS increased until 6 . hours, followed by a partial decrease until 12 . hours, and then increased again, reaching the peak level at 24 . hours and decreasing again until 48 . hours.

\section{$\operatorname{TAS}(\mathrm{mmol} / \mathrm{L})$}

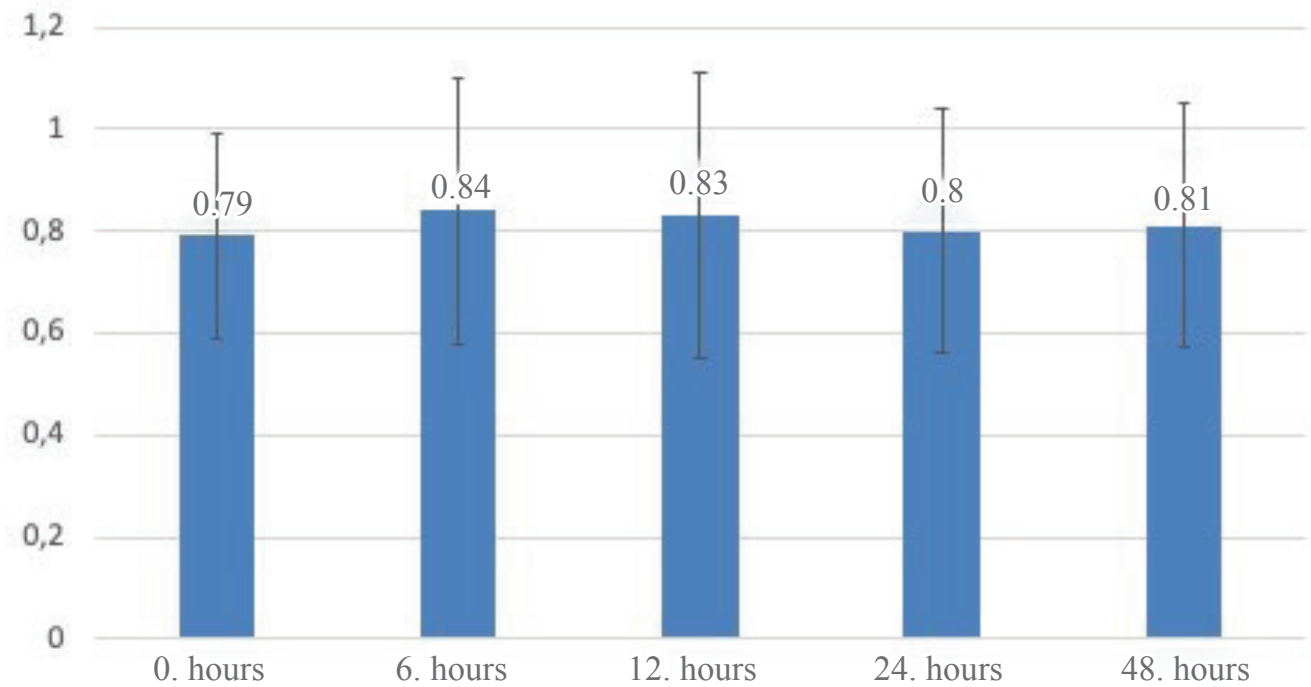




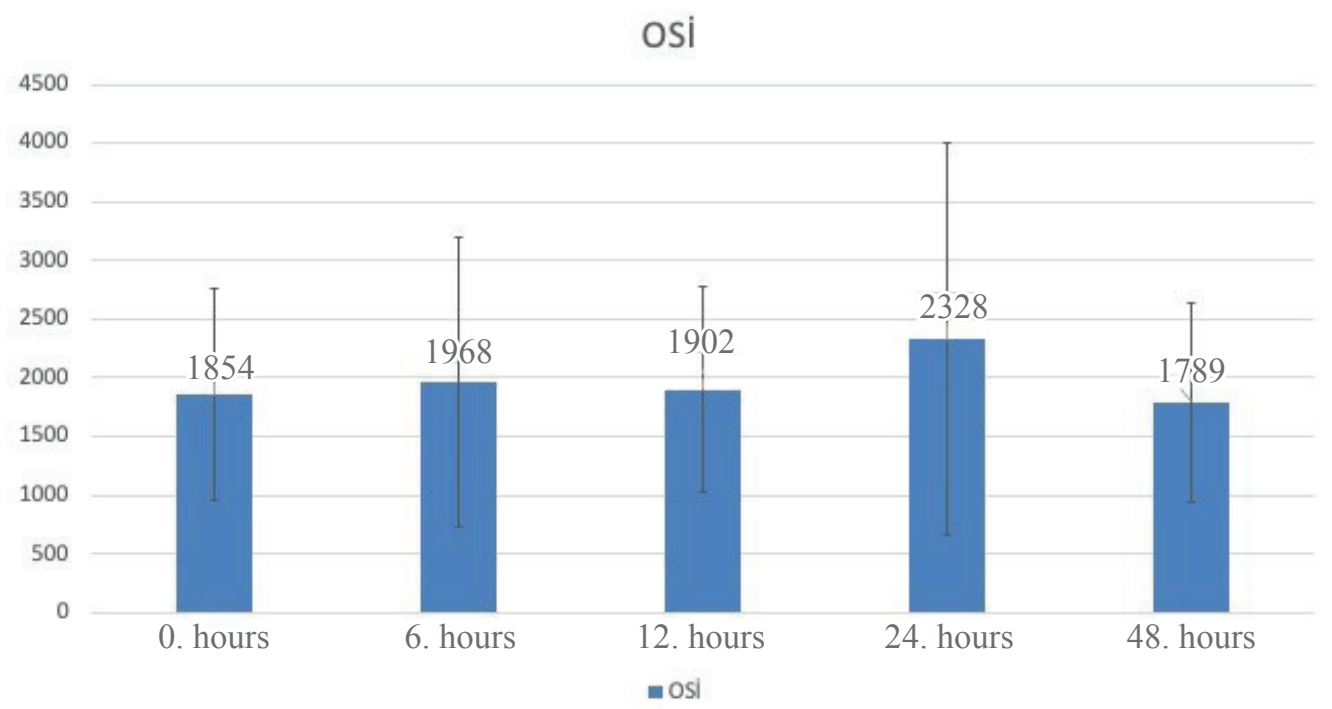

Figure 3. Course of OSI within 48 hours: The graphical course of OSI is parallel to TOS.

A significant correlation was found between TOS and CK $(r=0.36 ; p=0.008)$ and CK-MB $(r=0.46 ; p=0.001)$ at admission and OSI and CK $(r=0.32 ; p=0.03)$ and CK-MB $(r=0.36 ; p<0.01)$ at $48 \mathrm{~h}$. after diagnosis (Table 3 ). No other significant correlations were found.

The TOS, TAS, and OSI values were compared between patients with and without STEMI. The TOS values at admission were significantly higher in the patients with STEMI than in the patients with Non-ST elevation miyocardial infarction (NONSTEMI AMI) $(p=0.06)$ (Table 4). No other significant differences were found.

The patients were divided into three groups according to the number of stenotic vessels: single-vessel, two-vessel, and multi-vessel disease. The TOS, TAS, and OSI values were compared between these subgroups. A significant difference in TOS was found between the three groups at admission $(p=0.008)$ and $12 h$. after diagnosis $(p=0.02)$, and a significant difference in TAS was found between the three groups at admission $(p=0.009)$ and $6 h$. after diagnosis $(p=0.05)$ (Table 5). No significant differences were found between binary groups in a post hoc analysis.

\section{DISCUSSION}

This study found that oxidative stress increases in the early hours of AMI in young patients. There is a significant, yet low, correlation between oxidative stress markers and cardiac markers several hours after diagnosis. The most common traditional risk factors for young $\mathrm{AMI}$ patients were identified as smoking and hypertension. Consistent with our findings, Yıldırım et al. found that most of the patients who experience AMI at less than 40 years of age were male and that smoking is the most significant risk factor (12). However, Tungusubutra et al. found that family history is the most important risk factor for patients less than 45 years old with an acute coronary syndrome (13).

Another study reported that STEMI occurred more frequently in patients with an acute coronary syndrome under 35 than in older patients. The preferred treatment is primary $\mathrm{PCl}$, similar to our study (14). Çölkesen et al. found that single-vessel disease is the most frequent. The most common Ml presentation is anterior, and the LAD artery is most often the affected artery in patients under 35 years of age with STEMI, similar to our study (15).

In our study, the TOS and OSI values at admission were significantly higher in the patient group than in the control group.

Table 3. Pearson correlation coefficients between the cardiac markers and the oxidative stress parameters.

\begin{tabular}{lcc}
\hline & r coefficient & p value \\
\hline Creatine kinase (0. hour) - Total oxidant status (0. hour) & 0.36 & 0.008 \\
\hline Creatine kinase muscle-brain (0. hour) - Total oxidant status (0. hour) & 0.46 & 0.001 \\
\hline Creatine kinase (48. hour) - Oxidative stress index (48. hour) & 0.32 & 0.03 \\
\hline Creatine kinase muscle-brain (48. hour) - Oxidative stress index (48. hour) & 0.36 & 0.01 \\
\hline Correlation is significant for $p<0.05$ & & 0.03 \\
\hline
\end{tabular}


Table 4. Comparison of oxidative stress parameters between STEMI and NONSTEMI patients.

\begin{tabular}{lccc}
\hline & STEMI $(\mathbf{n = 3 6 )}$ & NONSTEMI $(\mathbf{n = 1 4 )}$ & p value \\
\hline Total oxidant status (0. hour) & $18.9 \pm 13.2$ & $13.1 \pm 7.8$ & $\mathbf{0 . 0 6}$ \\
\hline Total oxidant status (6. hour) & $16.3 \pm 8.9$ & $15.3 \pm 9.7$ & 0.5 \\
\hline Total oxidant status (12. hour) & $15.1 \pm 7.9$ & $13.8 \pm 5.3$ & 0.94 \\
\hline Total oxidant status (24. hour) & $17.1 \pm 11.7$ & $16.8 \pm 9.7$ & 0.84 \\
\hline Total oxidant status (48. hour) & $14.1 \pm 7$ & $11.7 \pm 7$ & 0.25 \\
\hline Total antioxidant status (0. hour) & $0.81 \pm 0.29$ & $0.76 \pm 0.08$ & 0.72 \\
\hline Total antioxidant status (6. hour) & $0.86 \pm 0.3$ & $0.77 \pm 0.8$ & 0.85 \\
\hline Total antioxidant status (12. hour) & $0.85 \pm 0.3$ & $0.77 \pm 0.08$ & 0.69 \\
\hline Total antioxidant status (24. hour) & $0.83 \pm 0.28$ & $0.78 \pm 0.07$ & 0.41 \\
\hline Total antioxidant status (48. hour) & $0.83 \pm 0.28$ & $0.77 \pm 0.09$ & 0.83 \\
\hline Oxidative stress index (0. hour) & $2053.4 \pm 977$ & $1932.6 \pm 1136$ & 0.6 \\
\hline Oxidative stress index (6. hour) & $2021.5 \pm 1318.2$ & $1833.13 \pm 1029.7$ & 0.97 \\
\hline Oxidative stress index (12. hour) & $1863.7 \pm 944.1$ & $2000.7 \pm 708.2$ & 0.46 \\
\hline Oxidative stress index (24. hour) & $2318.3 \pm 1834.5$ & $2356.2 \pm 942.4$ & 0.37 \\
\hline Oxidative stress index (48. hour) & $1822.9 \pm 832.8$ & $1703.1 \pm 942.4$ & 0.64 \\
\hline
\end{tabular}

However, there was no significant difference in the TAS values at admission. This may be explained by the late onset of the antioxidant response.

Ho et al. reported that the levels of the oxidative markers as 8-hydroxydeoxyguanosine (8-OHdG) and myeloperoxidase (MPO) were significantly higher and that the antioxidant capacity (measured as GPD and vitamin E) was significantly lower in patients with $\mathrm{MI}$ (17). In a recent study by Lo Presti et al., oxidant products were significantly higher, and antioxidant products were significantly lower in patients under 45 years old with AMI than in the control group (18). These findings are consistent with our study in terms of TOS and OSI, but not TAS. Oxidative stress is initiated early in the infarction stage. However, an antioxidant response occurs hours or days later. In the study conducted by Lo Presti et al., blood samples were collected in the late phase of Ml. The antioxidant response is likely to have been initiated, which may account for the difference in TAS results between their study and ours.

We found that the levels of troponin, CK-MB, TOS, and OSI values exhibited a similar pattern until 6 hours after diagnosis. It has been reported that plasma thioredoxin levels, which are an indicator of oxidative stress, decrease at $12 \mathrm{~h}$. after diagnosis and plateau at approximately four weeks after diagnosis (19). The difference in the patterns of oxidative stress indicators may be because different indicators were used in this study and that the ischemia-reperfusion injury may result in an increased oxidant capacity and oxidative index at more than 24 hours after diagnosis.
According to successful and unsuccessful reperfusion, another study that divided patients with STEMI after thrombolytic administration reported the antioxidant capacity at 1.5., 6., 12., and 24. h. and 2., 4., and 8. days after diagnosis (20). In the group that did not undergo successful reperfusion, the antioxidant capacity was significantly lower than that of the control group for as long as seven days after diagnosis. A significant increase in the antioxidant enzyme levels within the group's first hours underwent successful reperfusion. These levels started to decrease after the third day and regressed to normal levels in the following days. The antioxidant response in this study was partially similar to that observed in our study.

The number of studies examining the correlation of oxidative stress parameters with cardiac markers in $\mathrm{Ml}$ is quite limited, and the results are controversial. Furthermore, to the best of our knowledge, this is the first study of young AMI patients. Cardiac markers have been reported to be correlated with MPO levels at 24. and 96. h. after diagnosis of AMI (21). However, these results were found in an older patient population with different oxidative stress parameters, inclusion and exclusion criteria, and study design. Another study reported a correlation between Nt-proBNP and troponin-T but no correlations with oxidative stress markers (4).

Oxidative stress and antioxidant capacity in AMI patients were significantly higher and lower, respectively, in STEMI patients compared to NONSTEMI patients in a previous study (22). These results are consistent with those of our study. A significant, positive correlation was found between OSI and the 
Table 5. Comparison of oxidative stress parameters according to the number of stenotic vessels.

\begin{tabular}{lcccc}
\hline & One vessel ( $\mathbf{n = 3 3 )}$ & Two vessel $\mathbf{n}=\mathbf{1 1})$ & Three vessel $\mathbf{n}=\mathbf{5})$ & p value \\
\hline Total oxidant status (0. hour) & $13.8 \pm 7$ & $24.8 \pm 17.9$ & $25.3 \pm 16$ & $\mathbf{0 . 0 0 8}$ \\
\hline Total oxidant status (6. hour) & $16.5 \pm 10.2$ & $14 \pm 5.6$ & $18.6 \pm 8.1$ & 0.6 \\
\hline Total oxidant status (12. hour) & $12.9 \pm 5.7$ & $18.9 \pm 10$ & $18.8 \pm 4.1$ & $\mathbf{0 . 0 2}$ \\
\hline Total oxidant status (24. hour) & $17.1 \pm 11.9$ & $15.7 \pm 8$ & $18.8 \pm 4.1$ & 0.86 \\
\hline Total oxidant status (48. hour) & $13.5 \pm 7.6$ & $12.8 \pm 5.3$ & $15.5 \pm 7.4$ & 0.78 \\
\hline Total antioxidant status (0. hour) & $0.79 \pm 0.18$ & $0.64 \pm 0.2$ & $1.1 \pm 0.5$ & $\mathbf{0 . 0 0 9}$ \\
\hline Total antioxidant status (6. hour) & $0.8 \pm 0.1$ & $0.8 \pm 0.3$ & $1.1 \pm 0.48$ & $\mathbf{0 . 0 5}$ \\
\hline Total antioxidant status (12. hour) & $0.81 \pm 0.24$ & $0.81 \pm 0.3$ & $1 \pm 0.52$ & 0.39 \\
\hline Total antioxidant status (24. hour) & $0.82 \pm 0.2$ & $0.81 \pm 0.3$ & $0.83 \pm 0.4$ & 0.99 \\
\hline Total antioxidant status (48. hour) & $0.81 \pm 0.2$ & $0.83 \pm 0.2$ & $0.8 \pm 0.25$ & 0.99 \\
\hline Oxidative stress index (0. hour) & $1905.8 \pm 936.6$ & $2571.1 \pm 1199$ & $19612 \pm 1010$ & 0.61 \\
\hline Oxidative stress index (6. hour) & $2086 \pm 1378$ & $1734 \pm 781$ & $1761 \pm 1010$ & 0.73 \\
\hline Oxidative stress index (12. hour) & $1833.9 \pm 851$ & $2137.4 \pm 981$ & $2152.8 \pm 1012$ & 0.6 \\
\hline Oxidative stress index (24. hour) & $2442 \pm 1890$ & $2313 \pm 1230$ & $1526 \pm 368$ & 0.6 \\
\hline Oxidative stress index (48. hour) & $1811 \pm 937$ & $1880 \pm 762$ & $1552 \pm 455$ & 0.82 \\
\hline
\end{tabular}

GRACE risk scoring system for $\mathrm{MI}$, indicating the importance of OSI for these patients' prognoses (23).

The TOS and TAS were found to be significantly different in patients with one-, two-, or three-vessel disease in our study. However, these differences were only present at certain hours after diagnosis. Similar to our study, a previous study reported no significant difference in oxidative stress markers between patients with a high SYNTAX score (indicates the extent and the severity of coronary artery disease) and those with a low SYNTAX score (8). Another study, including patients below 35 with AMI, found that the SYNTAX score was positively correlated with the OSI and TOS values (24).

Treatments initiated in the first days of patients diagnosed with acute myocardial infarction, especially aspirin and statin, may also affect oxidative stress parameters $(25,26)$. It is known that both drugs reduce oxidative stress, but since the doses of these drugs were not obtained in our study, we cannot clearly understand their absolute effects on TOS, TAS, and OSI.

A small sample size, a single-center design, and a limited follow-up period of cardiac, oxidative, and antioxidant parameters limit this study. Multi-center studies with larger patient populations are needed.

In conclusion, oxidative stress increases in the early hours of AMI. The TOS and OSI values are correlated with cardiac markers at only some time points, and their prognostic values are limited in young AMI patients. TAS is not correlated with cardiac markers.
Ethics Committee Approval: Ethical approval was obtained from the Regional Ethics Committee (No:2020-39), and written consent was obtained from all patients.

Peer-review: Externally peer-reviewed.

Author Contributions: Conception/Design of Study - U.K.; Materials - U.K.; Data Collection - F.K., D.K., Analysis and/or Interpretation - A.K., Z.Y.; Drafting Manuscript - U.K., D.K.; Final Approval and AccountabilityC.K., A.K., Z.Y.

Conflict of Interest: The authors have no conflict of interest to declare.

Financial Disclosure: The authors declared that this study has received no financial support.

Etik Komite Onayı: Yerel Etik Kuruldan (No:2020-39) etik onay ve tüm hastalardan yazılı onam alınmıştır.

Hakem Değerlendirmesi: Dış bağımsız.

Yazar Katkıları: Çalışma Konsepti/Tasarımı - U.K.; Materyal: U.K.; Veri Toplama - F.K., D.K.; Veri Analizi/Yorumlama - A.K., Z.Y.; Yazma - U.K., D.K.; Son Onay ve Sorumluluk - C.K., A.K., Z.Y.

Çıkar Çatışması: Yazarlar çıkar çatışması bildirmemişlerdir.

Finansal Destek: Yazarlar bu çalışmada finansal destek almadıklarını beyan etmişlerdir. 


\section{REFERENCES}

1. Bast A, Guido R. Oxidants and antioxidants. Am J Med 1991; 91(3C): 2-13. [CrossRef]

2. Cochrane CG. Cellular injury by oxidants. Am J Med 1991; 91(3C): 23-9. [CrossRef]

3. Jane A. Leopold, Antioxidants, and Coronary Artery Disease: From Pathophysiology to Preventive Therapy. Cor Art Dis 2015; 26(2): 176-83. [CrossRef]

4. Kasap S, Gonenc A, Sener DE. Serum cardiac markers in patients with acute myocardial infarction: oxidative stress, C-reactive protein, and N-Terminal pro-brain natriüretic peptide. J Clin Bioch Nut 2007; 41: 50-7. [CrossRef]

5. Barbara E, Miso S, Pavel P. Inflammation markers in young post-myocardial infarction patients exhibiting various expressions of classic coronary risk factors. Cor Art Dis 2006,17: 325-30. [CrossRef]

6. Caimi G, Valenti A, Prenti L. Acute myocardial infarction in young adults: evaluation of the hemorheological pattern at the initial stage after 3 and 12 months. Ann Ist Sup Son 2007; 43(2): 139-43.

7. D'Oria R, Schipani R, Leonardini A, Natalicchio A, Perrini S, Cignarelli $A$, et al. The Role of Oxidative Stress in Cardiac Disease: From Physiological Response to Injury Factor. Oxid Med Cell Longev 2020; 5732956. [CrossRef]

8. Turan T, Menteşe Ü, Ağaç MT, Akyüz AR, Kul S, Aykan AÇ. The relation between intensity and complexity of coronary artery lesion and oxidative stress in patients with acute coronary syndrome. Anatol J Cardiol 2014; 15(10): 795-800. [CrossRef]

9. Romuk E, Wojciechowska C, Jacheć W, Nowak J, Niedziela J, Malinowska-Borowska J. Comparison of Oxidative Stress Parameters in Heart Failure Patients Depending on Ischaemic or Nonischaemic Aetiology. Oxid Med Cell Longev 2019; 7156038. [CrossRef]

10. Amanvermez R, Acar E, Günay M, Baydın A, Yardan T, Bek Y. Hsp 70, hs-CRP, and oxidative stress in patients with acute coronary syndromes. Bosn J of Basic Med Sci 2012; 12(2): 102-7. [CrossRef]

11. Chua SK, Hung HF, Shyu KG, Cheng JJ, Chiu CZ, Chang CM, et al. Acute ST-elevation Myocardial Infarction in Young Patients: 15 Years of Experience in a Single Center. Clin Cardiol 2010; 33(3): 140-8. [CrossRef]

12. Yıldırım N, Arat N. Comparison of traditional risk factors, natural history, and angiographic findings between coronary heart disease patients with age $<40$ and $>$ or $=40$ years old. Anatol $\mathrm{J}$ Cardiol, 2007; 7(2): 124-7.

13. Tungsubutra W, Tresukosol D, Buddhari W, Boonsom W, Sanguanwang S, Srichaiveth B. Acute coronary syndrome in young adults; the Thai ACS registry. J Med Assoc Thai 1990; 1: 81-90.
14. Schoenenberger AW, Radovanovic D, Stauffer JC, Windecker S, Urban $P$, Niedermaier G, Acute coronary syndrome in young patients; presentation, treatment, and outcome. Int J Cardiol 2011; 148(3): 300-4.

15. Colkesen AC, Acil T, Demircan S. Coronary lesion type, location, and characteristics of acute ST-elevation myocardial infarction in young adults under 35 years of age. Cor Ar Dis 2008; 19: 345-47. [CrossRef]

16. Erel $\mathrm{O}$. A new automated colorimetric method for measuring total oxidant status. Clin Biochem 2005; 38(12): 1103-11. [CrossRef]

17. Ho HY, Chang ML. Oxidative damage markers, and antioxidants in patients with acute myocardial infarction and their clinical significance. Biofac 2008; 34(2): 135-45. [CrossRef]

18. Lo Presti, Catania A, D'Amica T, Montana M. Oxidative stress in young subjects with acute myocardial infarction: evaluation at the initial stage and after 12 months. Clin Appl Thromb Hem 2008; 14(4): 421-7. [CrossRef]

19. Soejima H, Suefuji $H$, Miyamoto S, Kajiwaram I, Kojimo S, Hokamaki J, et al. Increased plasma thioredoxin in patients with acute myocardial infarction. Clin Card 2003; 26: 583-87. [CrossRef]

20. Himmetoglu S, Dincer Y, Bozcali E. Oxidative DNA damage and antioxidant defense after reperfusion in acute myocardial infarction. $J$ Inv Med 2009; 57(4): 595-9. [CrossRef]

21. Mocatta TJ, Pilbrow AP,Cameron WA, Senthilmohan R, Frampton $\mathrm{CM}$, Richards AM, et al. Plasma concentrations of myeloperoxidase predict mortality after myocardial infarction. JACC 2007; 22; 49(20): 2001-2. [CrossRef]

22. Serdar Z, Serdar A, Altın A. The relationship between oxidant and antioxidant parameters and severity of acute coronary syndromes. Act Card 2007; 62(4): 373-80. [CrossRef]

23. Shahzad S, Mateen S, Hasan A, Moin S. GRACE score of myocardial infarction patients correlates with oxidative stress index, hs-CRP, and inflammation. Immunobiology 2019; 224(3): 433-9. [CrossRef]

24. Aksoy S, Cam N, Gürkan U, Öz D, Özden K, Altay S, et al. Oxidative stress and severity of coronary artery disease in young smokers with acute myocardial infarction. Cardiol J 2012; 19: 381-6. [CrossRef]

25. Demirci B, Demir O, Dost T, Birincioglu M. Antioxidative effect of aspirin on vascular function of aged ovariectomized rats. AGE 2014; 36: 223-9. [CrossRef]

26. Kilit C, Koçak FE, Paşalı Kilit T. Comparison of the effects of highdose atorvastatin and high-dose rosuvastatin on oxidative stress in patients with acute myocardial infarction: A pilot study. Turk Kardiyol Dern Ars 2017; 45(3): 235-43. [CrossRef] 